\title{
IS THE IDEA OF THE COMMON EUROBONDS ISSUANCE IN THE EUROZONE SUSTAINABLE?
}

\author{
Nermina Pobrić *
}

\begin{abstract}
Although the concept of common Eurobonds issuance in the Eurozone was intensively considered during and after the euro area debt crisis, the proposals for implementing this idea appeared earlier, i.e. they have been presented since 1993 to the present day. By considering about fifteen proposals, as well as the expected economic effects of the implementing idea and the fulfillment of legal and political conditions for implementing the idea of the common Eurobonds issuance in the Eurozone, the author tends to answer the question: Is the concept about the common Eurobonds issuance in the Eurozone sustainable? The author concludes that the idea of the common Eurobonds issuance in the Eurozone is not possible in existing conditions, given that numerous proposals presented so far make the idea highly controversial and the possible bi-directionality in manifesting the economic effects and the political opposition additionally make the controversy stronger. However, the idea could be sustainable in the future if fiscal integration and political union in the euro area became strong.
\end{abstract}

KEYWORDS: Eurobonds, common Eurobonds, Eurobonds issuance, Eurozone Eurobonds

\section{INTRODUCTION}

The Eurobond market is the largest international capital market in the world. Eurobonds are used for trading In the Eurobond market. Eurobonds are commonly defined as sovereign or corporate bonds that are denominated in Euro-currency and that are simultaneously issued in several markets and sold to investors in numerous countries other than the country of the currency in

\footnotetext{
Associate professor at University of East Sarajevo, Faculty of Economics, Brčko; nermina.pobric.efb@gmail.com.
} 
which Eurobonds are issued. We will not consider those Eurobonds, but Eurobonds that are defined as possible European sovereign bonds jointly or both jointly and severally underwritten by all Eurozone governments and whose issuance was widely regarded as a solution to fiscal deficit problem during the debt crisis in the Eurozone. In other words, we will consider the Eurobonds which are shortly defined as "pooled" sovereign debt instruments of the Eurozone member states.

Although the idea of common Eurobonds issuance in the Eurozone was intensively considered during and after the euro area debt crisis, "the issue of common bond issuances by European states was raised long before the current crisis emerged, and indeed even before the euro area was launched"1. After the euro area was established, the idea of common Eurobonds issuance raised by the European states was considered in the context of increasing the economic and financial integration among euro area countries, improving the integration and efficiency of euro-area government bond markets, offering an alternative safe-haven to US Treasuries and reinforcing the role of the euro as a reserve currency, creating the fiscal union in the Eurozone in the future, improving the economic, financial and fiscal governance in the euro area, lowering the borrowing costs for all issuers of common Eurobonds, and, primarily, finding a mechanism for responding to the financial crisis and reducing the financial instability.

The issuance of common Eurobonds has been the object of intensive professional and political debate. The result of this debate is a large number of proposals of the issuance of bonds that are jointly or both jointly and severally guaranteed by the euro area sovereign states. The jointly guaranteed bonds are those in which the rest of the Eurozone jointly provide a guarantee for the repayment of public debt up to a certain maximum amount (guarantee level) to a financially less-disciplined issuer of the common Eurobonds. When one issuer of the common Eurobonds defaults, all Eurobonds co-issuers are responsible for its liabilities jointly and equally. In dependence on whether guarantee, i.e. financial support from the rest of the Eurozone is lost when the debt of the common Eurobonds issuer exceeds the guarantee level or not, there are Eurobonds with joint unlimited guarantee and Eurobonds with a joint limited guarantee. In the former, financial support from the rest of the Eurozone is not lost, but in the latter, this support is lost. The jointly and severally guaranteed bonds are those bonds issued as two tranches of the same issue, i.e. those bonds issued as senior and junior bonds alongside each other, where the junior bonds are not collectively guaranteed, unlike the senior bonds. Most propos-

Migiakis, P. M.: Reviewing the proposals for common bond issuances by the euro-area sovereign under a long-term perspective, Economic Bulletin, 37, 2012, Bank of Greece, p. 4354. URL: https://www.bankofgreece.gr/BogEkdoseis/econbull201212.pdf, p. 43. 
als of issuance of the common Eurobonds should contribute to resolving the problem of fiscal deficit in the Eurozone member states. It is not easy to choose an appropriate proposal. "Any relevant decision should take into account a longer-term perspective, as joint euro-area bonds should constitute an optimal choice at any phase of the economic cycle."2

When numerous proposals of the common Eurobonds issuance in the Eurozone occurred, they initiated a further debate on their effects, i.e. their pros and cons. The economists and politicians have particularly put focus on the issues such as cross-subsidization, moral hazard and free-riding on the creditworthiness of strong countries, on the liability of strong countries for a risk of other country as a form of bail-out, on disincentive of the less disciplined countries to fiscal discipline, as well as on the benefit of the idea for well-to-do economies and their interest in the idea.

To implement any proposal for the issuance of the common Eurobonds, the legal and political implementing conditions must be fulfilled. In implementing the idea of the issuance of the common Eurobonds, international law should play a relevant role because the issuers of the common Eurobonds are subjects of international law. However, the role of international law for the common Eurobonds will probably be limited. Apart from other things, three issues that at least partly depend on international law are: "(1) whether it is possible to sue a state in the courts of another state for disputes arising out of the sovereign bond (sovereign immunity) (Yang, 2015; Fox and Webb, 2013); (2) how responsibility for servicing bonds is divided into cases of state succession and a possible break-up of the Eurozone (Stanic, 2001); and (3) possible state defenses based on a state's temporary inability to service its bonds, or its inability to pay, such as economic necessity (Sykes, 2015)"3. Besides fulfillment of the legal conditions for implementing the idea of the issuance of the common Eurobonds in the Eurozone, the political will for that is of value too.

To answer to the question: Is the idea of the common Eurobonds issuance in the Eurozone sustainable?, we need to consider the objectives of the common Eurobonds issuance in the Eurozone, the proposals for implementing the idea of the common Eurobonds issuance in the Eurozone, the expected economic effects of implementing the idea of the common Eurobonds issuance in the Eurozone and the fulfillment of legal and political conditions for implement-

2 Migiakis, P. M.: Reviewing the proposals for common bond issuances by the euro-area sovereign under a long-term perspective, Economic Bulletin, 37, 2012, Bank of Greece, p. 4354. URL: https://www.bankofgreece.gr/BogEkdoseis/econbull201212.pdf, p. 43.

Waibel, M.: Eurobonds: Legal Design Features, Review of Law \& Economics, 12(3) 2016, p. 635-657. DOI: https://doi.org/10.1515/rle-2016-0046, p. 637. 
ing the idea of the common Eurobonds issuance in the Eurozone. Those four issues will be elaborated in the following four sections of the article. Finally, we come to the conclusion.

\section{THE OBJECTIVES OF THE COMMON EUROBONDS ISSUANCE IN THE EUROZONE}

The Eurobonds can be used for achieving different objectives in the Eurozone. We will put the focus on some of those objectives: risk sharing and fiscal discipline, promoting the further integration of the euro area bond markets, debt crisis prevention, and financial stability, providing the monetary policy transmission mechanism and financial markets activity, and EU-wide project financing. Not only are overlaps evident, but also disagreement among those objectives.

Issuance of the common Eurobonds enables risk sharing. It can provide ex-ante and ex-post transferring the risks among the euro area member states. Ex-ante transferring the risks can be achieved through lower spreads for some sovereigns. Ex-post transferring the risks would occur when one of the euro area member states is not able to meet its obligations. The possibility of transferring risks raises the issue of free riding and moral hazard. The concern about the free riding and moral hazard of some countries is greater as the safety net is stronger and the risk transferring is done to a higher degree. Thus, the viability of any proposal of the issuance of the common Eurobonds crucially depends on the ability of free riding and moral hazard to be controlled and reduced. To control and reduce the free riding and the moral hazard, powerful mechanisms for enforcing the fiscal discipline in a time-consistent manner could be satisfactory. Other mechanisms that rely on collegial rules and ex-post sanctions could be less effective.

Less segmented and more efficient euro area bond markets and also euro area financial markets will bring benefits to all. High liquidity in the integrated euro area bond markets would be beneficial to all. Its benefit will be in the form of a lower liquidity premium. Fully integrated euro area bond markets would ease managing the international investment positions and boost the role of the euro as a reserve currency. "In particular, small issuers (representing a tiny fraction of the euro area bond market) paying a high liquidity premium would mostly benefit from a jointly guaranteed Eurobond, but even Germany would benefit from having its bonds traded in a market potentially as thick and liquid as the US market."

4 Favero, C. A.; Missale, A.: Contagion in the EMU-the role of Eurobonds with OMTs, Review of Law \& Economics, 12(3) 2016, p. 555-584. DOI: https://doi.org/10.1515/rle-2016-0043, p. 559. 
As there was no formal mechanism of pooling the resources necessary for countries to overcome the crisis, the construction of appropriate arrangements for inter-governmental fiscal support to respond to the crisis is required. In this context, the common Eurobonds issuance in the Eurozone has been increasingly regarded. Hence, during the European sovereign debt crisis of 20102012 the important intention of the proposers of the common Eurobonds issuance was, among other things, to avoid the debt crisis that was not triggered by fiscal fundamentals and spreading the crisis to the economically stronger euro area member states. The idea of proposers of the common Eurobonds issuance in the Eurozone is to provide continuous market access for euro area member states with weaker fiscal fundamentals through jointly or both jointly and severally guaranteed Eurobonds. Thus, this access would be provided for the member states which are more exposed to changes in market conditions. Likewise, the possibility to issue the Eurobonds guaranteed by all euro area member states would also be beneficial for the countries in which the crisis spread from another country when the demand for new bonds drastically declined because of investors' fear that the debt market would panicky respond to uncertainty. In the Eurozone, the central bank does not act as the lender of last resort, but the role of a stabilizer of investors' expectations and market conditions may be taken over by the common Eurobonds. Therefore, issuance of the common Eurobonds may be beneficial for more countries than just for those experiencing a debt run. In other words, issuance of the common Eurobonds can help in improving the financial stability at both the European and global level. "However, it is worth noting that risk mutualization would not be without costs for safer member States. Even in the case that Eurobonds would not be issued by a country with financing difficulties, the option to do it would increase the expected liabilities of other member states. For this reason, Eurobonds jointly guaranteed by all member states may raise the borrowing costs on all types of bonds." 5

Issuance of the common Eurobonds could contribute to financial stability in the Eurozone through two mechanisms. The first mechanism acts through links between banks and their respective national sovereigns. When banks positively affect their respective national sovereign and vice versa and when those links are stronger, their effect on financial stability is also positive. The opposite is true when the interaction is negative. Namely, "banks (and other financial institutions) typically hold significant amounts of their respective government bonds as they are regarded as safe (and liquid) assets, or at least

5 Favero, C. A.; Missale, A.: Contagion in the EMU-the role of Eurobonds with OMTs, Review of Law \& Economics, 12(3) 2016, p. 555-584. DOI: https://doi.org/10.1515/rle-2016-0043, p. 560 . 
were so before the crisis. This "home bias" in sovereign bond holdings creates perverse feedback loops when concerns about sovereign risks translate into concerns about banks. And banks rely on a public safety net which is nationally funded, either explicitly (as in deposit insurance) or implicitly (in the form of guarantees and recapitalizations). In the absence of a common safety net (e.g., common deposit insurance, funding for recapitalization, all accompanied by common regulations and supervision, and centralized resolution authority), concerns about bank risks turn into concerns about the sovereign." second mechanism which could help contribute to the financial stability in the Eurozone implies the supply increase of safe assets. The risk of a flight to quality (or safety), the cross-border capital flows and the need for extraordinary liquidity provision from the European Central Bank could be reduced by increasing the supply of the safe common Eurobonds. In that way, creating safe common Eurobonds, among other things, would be beneficial for achieving financial stability in the Eurozone.

The issuance of the common Eurobonds could also contribute to the more efficient activity of the financial markets and providing the monetary policy transmission mechanism in the Eurozone. Those contributions can be achieved through an available unified and deep market for the European sovereign securities. As the financial market in the Eurozone has been very segmented and fragmented along national lines across the credit spectrum so far, the normal channels of transmission of monetary policy in that area are disrupted. "The ECB has embarked on a wide range of non-conventional policies over the last few years to restore the proper functioning of financial markets to allow for proper transmission of monetary policy. But these actions have, however, for the most part, only minimized the most adverse consequences of shocks and averted the liquidity crises and systemic banking failures, but not brought financial conditions back to normal."7 Therefore, in the future, a range of actions aimed at restoring the activity of financial markets and transmission mechanisms of monetary policy needs to include the affirmation of the issuance of the common Eurobonds in the Eurozone.

Finally, the objective of the common Eurobonds issuance in the Eurozone could be the financing of EU-wide projects (e.g. infrastructure objects that are usable in two or more euro area member states) and/or any expenditures

\footnotetext{
6 Claessens, S. et al.: Paths to Eurobonds, International Monetary Fund, WP/12/172, 2012, URL: https://www.imf.org/en/Publications/WP/Issues/2016/12/31/Paths-to-Eurobonds-26034, p. 7.

7 Claessens, S. et al.: Paths to Eurobonds, International Monetary Fund, WP/12/172, 2012, URL: https://www.imf.org/en/Publications/WP/Issues/2016/12/31/Paths-to-Eurobonds-26034, p. 8 .
} 
that increase output across the Eurozone through spillover effects. Currently, the potential of financing the specific projects through the Eurobond program would be limited, so that a liquidity premium would have to be paid. The potential of EU-wide project financing would be increased by introducing the Eurobonds jointly or both jointly and severally guaranteed by the euro area member states. In this context, advantages of issuance of the common Eurobonds in the Eurozone could be seen from the perspectives of both individual countries and the Eurozone as the whole. From the perspective of individual countries, a potential advantage of financing by issuing the Eurobonds would be the possibility to create fiscal space in national budgets without lengthy negotiations in budget flexibility. From the perspective of the Eurozone, the announcement of a common program would enhance the credibility of EU institutions by signaling a political will for greater fiscal unity and cooperation, thus paving the way for a deeper reform of EU fiscal governance. ${ }^{8}$

\section{THE PROPOSALS FOR IMPLEMENTING THE IDEA OF THE COMMON EUROBONDS ISSUANCE IN THE EUROZONE}

Various authors, not only academics but also politicians, have proposed different variants of a model of issuing the common Eurobonds in the euro area. Among the proposals that have been presented since 1993 to the present day, we will elaborate those given by some academics, such as Giovannini, Grauwe and Moesen, Delpla and Weizsäcker, Boonstra, Hellwig and Philippon, Baglioni and Cherubini, Gopal and Pasche, Hild et al., Brunnermeier et al. and Muellbauer, those proposals given by some institutions, such as European Commission and the German Council of Economic Experts, as well as proposals given by some politicians, such as Delors, Juncker and Tremonti, Quadrio Curzio by himself and with Prodi.

The first formal proposal for issuance of the common Eurobonds by euro area member states was introduced in one of the reports which Giovannini Group prepared for the European Commission in 2000. In that report, the idea of issuance of the common Eurobonds in the Eurozone was the main subject. Namely, two of four proposed ways for deepening the euro area primary sovereign bond markets and, finally, for strengthening the financial integration in euro area bond markets were related to the "central debt issuance, at the Community level, backed by joint guarantees from euro area sovereign states. To this end, it should be noted that the Giovannini Report argues that joint

8 quoted according to Favero, C. A.; Missale, A.: Contagion in the EMU-the role of Eurobonds with OMTs, Review of Law \& Economics, 12(3) 2016, p. 555-584. DOI: https://doi. org/10.1515/rle-2016-0043, p. 561. 
debt issuance by several euro area Member States would lead to a decrease in the average borrowing cost for euro area countries while increasing the role of euro as a reserve currency." 9 As Favero \& Missale wrote: "Issuance of a common Eurobond, first analyzed in the Giovannini Group Report (2000), was originally viewed as a strong form of debt management cooperation with the potential of promoting further market integration and greater liquidity." 10

Besides promoting further financial integration and greater liquidity in the euro area bond markets, the proposals are given after the debt crisis were also aimed at achieving fiscal sustainability and financial stability in the Eurozone in the near future. Similarly, the proposals were aimed at establishing the fiscal union in the euro area, when and if it would be possible. The first proposal to overcome the crisis was formulated by De Grauwe and Moesen as early as May 2009. Those authors proposed that an EU institution, i.e. the European Investment Bank issues the collectively guaranteed euro-denominated Eurobonds with an interest rate which is equal to a weighted average of the yields on government bonds in the national government bond markets of countries which participate in the common Eurobonds issuance arrangement. The collective guarantee would be provided by euro area member states which participate in the agreement. The share of participating countries in the collective guarantee and their weights in the weighted average interest rate on the common Eurobonds would be determined according to the participation of each country in the capital of the European Investment Bank. Thus, the nominal interest rate would be differentiated across the participating countries and it would be calculated based on their market-based cost of debt. Proceeds from the issue would be channeled to the participating countries according to the weighting scheme, too. As the participating countries would pay the same rate as they pay on their government bonds in the national government bond markets, the possibilities of free-riding of weaker countries would be eliminated. Furthermore, participating countries with funding difficulties will have indirect access to the markets if the regarded proposal is implemented. That means that the proposal will guarantee to fund for all participating countries. The proposal will also guarantee the safety for investors in the collectively guaranteed Eurobonds, which will make investors gradually increase their trust in those instruments and the market.

\footnotetext{
9 Migiakis, P. M.: Reviewing the proposals for common bond issuances by the euro-area sovereign under a long-term perspective, Economic Bulletin, 37, 2012, Bank of Greece, p. 4354. URL: https://www.bankofgreece.gr/BogEkdoseis/econbull201212.pdf, p. 46.

10 Favero, C.; Missale, A.: Sovereign spreads in the Eurozone: which prospects for a Eurobond?, Economic Policy, 27(70) 2012, p. 231-273. DOI: https://doi.org/10.1111/j.1468 0327.2012.00282.x, p. 233.
} 
In May 2010 Delpla and Weizsäcker presented their frequently discussed and well-known "Blue-Red bond" proposal. According to their proposal, the sovereign debt of Eurozone member states should be divided into two parts: blue debt and red debt. To achieve such a division of the sovereign debt, a euro area entity should carry out the mutualization of the public debt of each euro area member state up to at most Maastricht rate of $60 \%$ of GDP and centrally issue the bonds based on this pool of the sovereign debt. Based on the remainder sovereign debt over $60 \%$ of GDP, the bonds should be issued on a national level, i.e. by individual sovereigns. Thereby, two bond categories would exist. The first category would carry the name Blue bonds, and the second one would carry the name Red bonds. The Blue bonds would be jointly and severally guaranteed by participating countries, they would have senior status (i.e. enjoy seniority over the Red bonds), they would be a super-safe asset which should never default and with top credit assessments (at AAA level), they would be an extremely liquid asset and they would have a low yields. The issuance of Blue bonds should help in reducing the borrowing costs for some sovereigns, in insulating the banks from national sovereign risks, in reducing the flight to safety, in creating a new benchmark bond and in affirming the euro as the main reserve currency. The Red bonds would be issued as junior debt, with higher yields and at a higher (marginal) cost (i.e. risk-adjusted interest rates) reflecting the creditworthiness of each country, in comparison to the Blue bonds. Sovereign borrowing by issuing the Red bonds would make borrowing more expensive, "especially for countries pursuing unsustainable fiscal policies or lacking fiscal credibility." ${ }^{\prime 11}$ Provided that borrowing costs would rise with increasing indebtedness beyond the Maastricht rate of $60 \%$ of GDP, highly indebted countries would have an incentive to achieve and maintain fiscal discipline by bringing their debt to below $60 \%$ of GDP. Furthermore, the Red bonds would be illiquid and riskier and they would have the same default risk as it was before their issuance. Apart from that, every country would be responsible for its debt beyond $60 \%$ of GDP. This means that "Red bonds could never be guaranteed by another country and could not be bailed out by EU rescue mechanisms (EFSF, EFSM or ESM)"12 "The introduction of Blue and Red Bonds could either occur gradually, with Blue and Red Bonds replacing legacy debt as it is rolled over or in a big bang in exchange for the entire legacy debt stock. The main advantage of the gradual approach is that it would allow

11 Delpla, J.; Von Weizsäcker, J.: Eurobonds: The blue bond concept and its implications, Bruegel policy contribution, 2011/02, 2011, Bruegel, Brussels, URL: http://hdl.handle. net/10419/45535, p. 2.

12 Gilbert, N. D. et al:: Towards a Stable Monetary Union: What Role for Eurobonds?, De Nederlandsche Bank Working Paper, 379, 2013, URL: https://ssrn.com/abstract=2269538 or http://dx.doi.org/10.2139/ssrn.2269538, p. 21. 
the system to establish its credibility gradually with markets and European citizens, with some adjustments readily possible during the five to ten-year introductory period. The main advantages of a big bang solution are twofold. First, a deeply liquid pool of Blue debt would be created overnight, rather than having to wait for many years for the full benefits of the system. Secondly, the big bang exchange could be potentially used for a comprehensive debt restructuring if the market view on debt sustainability in some of the crisis countries was to turn out to be accurate." 13 The authors of the proposal considered that an independent institution should be responsible for managing the issuance and market placement of the bonds. Since the presentation, the proposal has subsequently been augmented and amended.

Boonstra proposed that Eurobonds be issued through a newly established independent central financing agency for the EMU which he called "EMU Fund". This fund would lend the funds raised from the investors in the Eurobonds to the voluntarily participating EMU countries. The participating EMU countries would have to pay a premium over the Eurobond rate for borrowed funds. "This premium will be based on the deficit and debt deviations from the average levels of Germany and France. Only countries performing worse than Germany and France will pay a premium." ${ }^{14}$ All EMU countries participating in the proposed mechanism of financing would jointly and severally guarantee for the Eurobonds. Boonstra's approach would bring out some effects to the participating countries, for example access to the Eurobond financing would be guaranteed and unlimited, liquidity of participating countries would be increased, borrowing costs would be reduced, fiscal discipline of participating countries would be strengthened, the risk of contagion between participating countries would be reduced and participating countries would be sheltered against speculation. However, "in Boonstra's proposal, it is highly questionable if a penalty interest rate alone is enough to prevent moral hazard - especially if at the same time access to Eurobond funding is guaranteed and unlimited." 15

In November 2011, the European Commission issued a Green paper in which it proposed the issuance of Stability Bonds. In this proposal, three options

13 Delpla, J.; Von Weizsäcker, J.: Eurobonds: The blue bond concept and its implications, Bruegel policy contribution, 2011/02, 2011, Bruegel, Brussels, URL: http://hdl.handle. net/10419/45535, pp. 5-6.

14 Eijffinger, S. C.: Eurobonds-Concepts and implications, Briefing Note to the European Parliament, 2011, URL: http://www.sylvestereijffinger.com/wp2/wp-content/uploads/EP\%20 Briefing\%20Paper\%20March\%202011.pdf, p. 4.

15 Gilbert, N. D. et al:: Towards a Stable Monetary Union: What Role for Eurobonds?, De Nederlandsche Bank Working Paper, 379, 2013, URL: https://ssrn.com/abstract=2269538 or http://dx.doi.org/10.2139/ssrn.2269538, p. 21. 
were offered for Stability Bonds. According to the first option, national bond issuances would completely be substituted by Stability Bond issuances. Debts arisen by issuing the Stability Bonds would be debts of member states. The second and third options implied that national bond issuances should only partially be replaced by Stability Bond issuances. Those options resemble more the previously regarded "Blue-Red bond" proposal. The difference between those two options is that the part of national debt replaced by Stability Bonds would jointly be guaranteed by euro area sovereigns, according to the second option, but part of national debt replaced by Stability Bonds would severally be guaranteed by each euro area sovereign, i.e. each sovereign would guarantee for its share of the debt, according to the third option. Part of the national bond issuances that were not replaced by Stability Bond issuances would remain a national liability. The issuance of Stability Bonds would be aimed at restoring stability in the financial markets of the euro area.

Apart from the European Commission, the German Council of Economic Experts gave another proposal in November 2011. That proposal is converse in comparison to the "Blue-Red bond" proposal in many ways. "The so-called Redemption Pact would transfer the debt of a member state in excess of $60 \%$ of GDP (if any) into a European Debt Redemption Fund (ERF) for which all members would be jointly and severally liable. The total covered debt would amount to some $27 \%$ of Eurozone GDP, with Germany, Italy, and Spain as the largest participants. In return, the countries would agree to repay ERF the transferred debts within 25 years, with these obligations superior to remaining national debts and possibly backed up by collateral and dedicated tax revenues from each country. During a roll-in phase of 3 to 4 years, participating countries would, by transferring obligations coming due up to their issued quota of guaranteed debt, be able to meet much of financing requirements. Any other debt would remain of national responsibility and be junior."16

Also in November 2011, Hellwig and Philippon proposed another version to the "Blue-Red bond" proposal. However, their proposal was limited to the issuance of short-term common securities, i.e., Euro-bills. The Euro-bills would be the financial instruments with a maturity of shorter than a year, which are issued by a common debt agency and jointly and severally guaranteed by euro area member states. At any point, countries could not have more than $10 \%$ of GDP in the Euro-bills. Due to short maturities, the Euro-bills would be more superior to the longer-term Eurobonds and they would simplify the achievement of the continuous fiscal discipline in the Eurozone. Gilbert et al. wrote

16 Claessens, S. et al.: Paths to Eurobonds, International Monetary Fund, WP/12/172, 2012, URL: https://www.imf.org/en/Publications/WP/Issues/2016/12/31/Paths-to-Eurobonds-26034, p. 9 . 
that "the introduction of Euro-bills might, to some extent, help countries retain market access. As argued by the authors of the proposal, it might also create a "safe asset" for the financial sector. There seem to be few negative side effects. However, as the access to Euro-bills is very limited (max 10\% of GDP), the proposal does not guarantee EMU member states access to finance in times of stress. Judged by our criteria, the proposal is therefore too limited in size and scope to stabilize EMU."'17

In the same year, Baglioni and Cherubini developed a complex model of issuance of the common Eurobonds with no cross-subsidization. According to their model, part of the national public debt of euro area countries should be converted into Eurobonds. To achieve this, a European Debt Agency (EDA) should be established. Then, this agency should issue the Eurobonds in the open market, raise funds from investors and lend money to the governments of euro area countries, up to a specific level of the debt-to-GDP ratio. Each government would have to transfer the cash to the EDA in proportion to the riskiness of its country "if it were to issue its senior debt (in a domestic trenching scheme) and make it risk-free... The EDA is endowed with a cash transfer from the governments that equals the expected loss on its overall exposure with the euro area governments. This is to ensure that the Eurobonds can be issued at the risk-free rate. The EDA should pass this benefit on to the sovereign borrowers, who can, in turn, borrow from the EDA at the riskless rate." ${ }^{18}$ From the abovementioned, it follows that there would be no cross-subsidization in this model of issuance of the common Eurobonds. Besides that, this model is characterized by the possibility of reducing the cost of public debt for some countries in the euro area, with no cost increase for the others, the ability to enforce the governments to decrease their deficits, the seniority of the claim of the EDA relative to the other public debt securities, the jointly (i.e. by all participating countries) guaranteed liabilities of the EDA, and surplus and deficits diversification across countries.

The model of issuance of the common Eurobonds developed by Gopal and Pasche is closely related to the model developed by Baglioni and Cherubini and it is also the extension of "Blue-Red bond" proposal. According to their proposal, sovereign debt of euro area countries should be divided into two parts: blue debt and red debt. A common agency which Gopal and Pasche called the European Central Agency (ECA) would issue the blue bonds, i.e. Eurobonds.

17 Gilbert, N. D. et al:: Towards a Stable Monetary Union: What Role for Eurobonds?, De Nederlandsche Bank Working Paper, 379, 2013, URL: https://ssrn.com/abstract=2269538 or http://dx.doi.org/10.2139/ssrn.2269538, p. 22.

18 Baglioni, A.; Cherubini, U.: Eurobonds: A Quantitative Approach, Review of Law \& Economics, 12(3) 2016, p. 512. 
The ECA would use the raised funds to lend money to the governments, up to a specified level of the total debt, e.g. $80 \%$. The rest of the national sovereign debt over the blue debt would refer to the red debt. The issuer of the red bonds could only be every euro area country individually, irrespective of the level of their public debt. The Eurobonds issued by ECA would be seniors relative to the other liabilities of the government. The ECA should be an independent institution that could be organized as a financial company or special purpose vehicle, as suggested by Gopal and Pasche. "The ECA is endowed with collateral, funded by the participating governments. This collateral should be a safe asset like cash deposits or credible guarantees - similar to the ESM. One can also think about gold, but other assets (e.g. real estate) seem to be less suitable."19 The amount of collaterals should be sufficient to ensure that "the investors are willing to pay an almost risk-free rate for the blue bond. The required collateral for each participating nation is calculated according to their individual default risk, the expected losses and their variance - information which are obtained from the red bond market perception." ${ }^{20}$ With this collateral, cross guarantees would be provided. The proposers expected that cross guarantee would create no moral hazard because the individual collateral contributions to the ECA would automatically increase when investors detect higher risks and charge higher risk premiums on the bonds which are traded in the red bond market. Furthermore, cross-subsidization would be avoided because the collaterals would be proportional to individual risk. Paying collateral would generate the difference between the almost risk-free rate on the blue bonds and the effective interest rate which countries pay. The effective interest rate would be equal to the sum of the almost risk-free rate on the blue bonds and the expected loss of the collateral.

In 2011, Hild et al. suggested a new Eurobond structure which would be based upon techniques of both modern financing and securitization. Specifically, they proposed a full substitution of existing national sovereign bonds by the Eurobonds commonly issued by euro area member states. The three key participants in the process of substitution would be the originators, an independent special purpose vehicle and the investors. A special purpose vehicle would buy existing national sovereign bonds in the secondary market. Then, it would is-

\footnotetext{
19 Gopal, M.; Pasche, M.: Market-based Eurobonds Without Cross-Subsidisation, Working Papers on Global Financial Markets from Friedrich-Schiller-University Jena and University of Hall. Wittenberg, Foundations of Global Financial Markets - Stability and Change, 2012-37, 2012, URL: http://hdl.handle.net/10419/94482, pp. 4-5.

20 Gopal, M.; Pasche, M.: Market-based Eurobonds Without Cross-Subsidisation, Working Papers on Global Financial Markets from Friedrich-Schiller-University Jena and University of Hall. Wittenberg, Foundations of Global Financial Markets - Stability and Change, 2012-37, 2012, URL: http://hdl.handle.net/10419/94482, p. 5.
} 
sue the structured Eurobonds covered i.e. collateralized by the receivables of the national sovereign bonds issued by the euro area countries. An existing independent institution or a newly created entity could take over the role of the special purpose vehicle. No country should have an impact on the operations of the special purpose vehicle. All property rights have to be decoupled in order to avoid destabilizing effects. The special purpose vehicle would issue a set of debt securities with diverse seniority, risk, rating and yield features. In that way, the trenching of the Eurobonds would be carried out. A senior tranche of Eurobonds would bear a higher rating, it would have seniority and it would be more immune to the default in comparison to a junior tranche of the Eurobonds. A junior tranche of the Eurobonds would only be paid once the liabilities that refer to the senior tranche have been settled in full. The potential benefits of issuing the structured Eurobonds would be multiple. In that context, the authors of the proposal wrote: "By pooling and trenching, the default risk is concentrated in the subordinated part of the capital structure, resulting in a relatively large share of less risky securities. Due to the reduction in the overall risk premiums, the interest savings can be realized as the interest payments for the pooled Eurobond are lower than the sum of the interest payments of the individual countries." ${ }^{21}$ Additionally, issuance of the structured Eurobonds could be beneficial for euro area countries because it enables establishing a new liquid asset, meeting the investors' preferences and increasing the credit quality of the Eurobonds above that of the underlying asset pool and, also, because it enables the participating countries to only partially respond for liabilities referred to the issued structured Eurobonds.

Similarly to Hild et al. and also in 2011, Brunnermeier et al. proposed the common safe debt securities issuance which is based upon pooling and trenching techniques. According to their proposal, a European debt agency would buy national sovereign debt in the secondary market, up to $60 \%$ of the GDP of each EMU member country. Then, in exchange for bought debt, the agency would issue two types, i.e. two tranches of securities. The European Safe Bonds (ESBies) would make the senior tranche. The European Junior Bonds (EJB) would make the junior tranche of this structure. ESBies would have the role of a safe asset for the banks. EJB would serve as shock-absorber. The two previously mentioned proposals of the two tranches of structured securities can be explained as follows: "First, banks holding ESBies would no longer be exposed to national sovereign risks, but combined Eurozone risk; and second, any flight to safety would be from the EJBs, the junior (risky) bond, to the ESBies and

${ }^{21}$ Hild, A. M. et al.: Structured eurobonds: Limiting liability and distributing profits, JCMS: Journal of Common Market Studies, 52(2) 2014, p. 250-267. DOI: https://doi.org/10.1111/ jems.12104, p. 251. 
not, as now, from one country to another, thus reducing a source of multiple equilibriums and instability." 22 The structured securities issued in accordance with this proposal would not cover the use of the cross-country guarantees. Due to no sovereign guarantees requirement, the proposal would face fewer hurdles to implementation.

Two years later, Muellbauer suggested the issuance of jointly underwritten euro-insurance bonds, so-called conditional Eurobonds in the euro area. The issuer of those Eurobonds would be a euro area debt management agency. The debt management agency would set the maturity profile of conditional Eurobonds that it issues each year based on "investor preferences revealed in the market. Individual countries would have no control over the maturity profile of their new debt obligations. The collective maturity profile would set the debt repayment schedule of each country, given each country's new debt issue." 23 The value of issuance would be equal to the sum of the funding requirements of euro area countries. Outside investors would trade by the conditional Eurobonds of a given maturity at the same price. However, individual countries would pay a different interest rate on their conditional Eurobonds to the euro area debt management agency. For countries with weak fundamentals, the interest rate would be higher because it would contain a higher country risk premium. Country risk premium would be equal to the weighted average of risk factors, where long-run economic fundamentals are used as risk factors. The risk factors and their weights would have to be negotiated between the euro area member states. Country risk premium would be paid into a common insurance fund. It would be used to ensure the underwriting countries against the higher risk of future default of any member state. Besides country risk premium, countries could post collateral in the form of gold and the foreign exchange reserves with the euro area debt management agency. The required collateral should be proportional to the overall risk for each country. "In the event of a future default or debt write-down by a member state, the build-up of payments in the insurance fund, plus the collateral, would be available to cover the countries underwriting the joint euro-insurance-bond issue. ... In the unlikely event of such funds being insufficient, the cost over-run could be added to each country's share in the collective debt, in proportion to their GDP." ${ }^{24}$

\footnotetext{
22 Claessens, S. et al:: Paths to Eurobonds, International Monetary Fund, WP/12/172, 2012, URL: https://www.imf.org/en/Publications/WP/Issues/2016/12/31/Paths-to-Eurobonds-26034, p. 9.

23 Muellbauer, J.: Conditional eurobonds and the Eurozone sovereign debt crisis, Oxford Review of Economic Policy, 29(3) 2013, p. 610-645. DOI: https://doi.org/10.1093/oxrep/grt032, p. 638 .

24 Muellbauer, J.: Conditional eurobonds and the Eurozone sovereign debt crisis, Oxford Review of Economic Policy, 29(3) 2013, p. 610-645. DOI: https://doi.org/10.1093/oxrep/grt032, p. 639.
} 
Finally, the proposals emerging from the political arena, and which we will elaborate, are those created by Delors, Juncker and Tremonti, Quadrio Curzio by himself and with Prodi. In their proposals, politicians usually have put focus on the issuance of growth bonds and stability bonds so far. Thus, in 1993 during his term of office as president of the European Commission, Jacques Delors proposed the issuance of growth bonds that he called Union-bonds. The EU budget would act as collateral for the Union-bonds. This means that the European Union would act as a guarantor for the issued Union-bonds. The aim of the issuance of those growth bonds was promoting economic growth by financing the European investment in large infrastructural projects in fields such as transport, telecommunications, energy, and environment.

The issuance of stability bonds was proposed, among others, by Jean-Claude Juncker, during his term of office as president of the Eurogroup, and by Giulio Tremonti, during his term of office as Minister of Economy and Finance in the Italian Government. This was proposed in December 2010, when Juncker and Tremonti informally called for the issuance of Eurobonds, which they called European sovereign bonds. According to the proposal, an independent European Debt Agency (EDA) would issue Eurobonds "in an amount equal to $40 \%$ of the GDP of the EMU and thus of the Eurozone Member States. ... On the basis of these securities the EDA should then purchase national debt securities of the Member States, both during issuance and on the secondary market, to act as their creditor and thereby replace the market itself. ... The EDA would purchase the national debt securities of the Member States at higher prices than normal investors since EDA would not require a risk premium to retain the securities to maturity." 25 This approach was intended to be used for restructuring the public debt in the euro area countries. The restructuring has seemed a realistic aim of the approach because it was expected that the EDA could immediately stimulate the countries to improve their financial position by decreasing their fiscal deficits. Besides restructuring the public debt, the issuance of Eurobonds aimed at creating a liquid and deep market for European sovereign debt securities. In this way, the EDA would make the Eurobonds attractive for investors. However, the proposal by Juncker and Tremonti is eliminated because it is not illustrated in detail and it is very similar to the other proposals.

Quadrio Curzio promoted the issuance of Union-Eurobonds. His idea arose as a result of a combination of two previously elaborated proposals. Thus, the Union-Eurobonds are hybrid of Union-bonds and Eurobonds. The issuance

25 Quadrio Curzio, A.: On the Different Types of Eurobonds, Economia politica, 28(3) 2011, p. 279-294. DOI: 10.1428/35912 URL: https://www.rivisteweb.it/doi/10.1428/35912, pp. 283284. 
of Union-Eurobonds would aim at providing support to the partial restructuring of the public debt in the euro area countries and financing the investment in European large infrastructural projects. Apart from the Union-Eurobonds, Quadrio Curzio suggested the issuance of Project-bonds and Golden Euro-Development Bonds. The issuer of the latter would be a golden Euro-Development Fund (EDF), on behalf of euro area member states. The EDF should hold the gold reserves of Eurozone countries as collateral. Given its safety based on the golden collateral, the Golden Euro-Development Bonds would certainly be placed in the market. The EDF could use the raised funds in three ways. "The first destination would be the financing - only partial, as with Eurobonds - of national debt securities, on behalf of EMU States. These States would, in turn, be responsible for paying interest to the EDF on loans received. The rate should be higher than the interest EDF would have to pay to its subscribers, but still lower than the rates individual States currently have to pay on the market, given that all Eurozone countries are forced to pay a risk premium, with the single exception of Germany."26 The second way in which EDF could use the raised funds would involve the financing of merger operations among the firms belonging to the banking and industrial system. The result of such use of the funds was expected to be the mergers of firms within the Eurozone, which should facilitate the restructuring of enterprises participating in merger operations, as well as strengthening their position. The last destination for funds that EDF raised would be financing the European investment in large infrastructural projects aimed at strengthening of the internal infrastructures of the euro area.

Following the three above elaborated proposals, as well as other proposals, Quadrio Curzio and Prodi proposed the issuance of Euro-UnionBonds. The issuer of those bonds would be a European Financial Fund (EFF). The same as the EDF, the EFF should hold the gold reserves of Eurozone countries as collateral. Contrary to the EDF, the EFF could also hold the other assets, such as bonds and shares. In other words, the EDF would only be based on gold reserves, but the EFF would be based on a wider set of assets. Furthermore, the contribution of each euro area member states to the EFF would be in proportion to their stakes in the ECB. Besides those differences, there is one more difference between the EDF and the EFF concerning destinations of raised funds. Namely, the EFF could not use the raised funds for the financing of merger operations, while the EDF could use them for that, as earlier noted. Other features of the Euro-UnionBonds would be common to those of five bond types that were discussed by politicians.

\footnotetext{
26 Quadrio Curzio, A.: On the Different Types of Eurobonds, Economia politica, 28(3) 2011, p. 279-294. DOI: 10.1428/35912 URL: https://www.rivisteweb.it/doi/10.1428/35912, p. 287.
} 
In spite of numerous proposals and the possibility to see the issuance of common Eurobonds from different perspectives, the European common Eurobonds remain highly controversial.

\section{THE EXPECTED ECONOMIC EFFECTS OF IMPLEMENTING THE IDEA OF THE COMMON EUROBONDS ISSUANCE IN THE EUROZONE}

The introduction of the common Eurobonds in the euro area could contribute to the better activity of the Eurozone in some fields as well as to the worse activity of the Eurozone in some other fields. In other words, implementing the idea of the common Eurobonds issuance in the Eurozone could have some positive and negative economic effects. The expected economic effects of implementing the idea of the common Eurobonds issuance vary with the proposals. Apart from other things, a Eurobond solution could have important implications for the liquidity of European bond markets, for the access to the financial markets, insurance against credit risk and borrowing costs for all member states, for the flexibility in debt management and the thick market set-up costs.

Creating the common European government bond market would promote further financial market integration in Europe, especially on the supply side. By unifying the European government bond market, its liquidity would almost certainly enhance. The extent to which liquidity of the integrated bond market would increase depends on the degree of member states participating in different schemes for the introduction of the common Eurobonds in the euro area. The liquidity of integrated bond market would be at a higher level when the issues were larger and more regular, when the outstanding volumes of the Eurobond reached higher levels and when the integrated bond market replaced the national markets of the member states in larger degrees, but at least of the member states with smaller funding needs. Greater liquidity of the integrated bond market would reduce the liquidity premiums and, consequently, the borrowing costs for euro area member states, particularly for their smaller and medium-sized issuers.

The introduction of the common European government Eurobonds could ensure cheaper and continuous access to the financial markets and therewith guaranteed to fund for all euro area member states. Precisely, it could provide access to the financial markets under better conditions for those countries under distress, i.e. for weaker countries during crises. It could also provide insurance against credit risk to weaker member states during crises. To make this happen, the common Eurobond issues would have to be backed by the explicit or implicit guarantees of transferring the responsibility for liabilities from 
weak to strong countries. In other words, the common Eurobonds should have a joint and cross guarantees of the issuing countries or they should be issued by some EU institutions. Many proposals elaborated above for implementing the idea of the common Eurobonds issuance in the Eurozone meet one of those requirements for providing the insurance against credit risk. Notwithstanding, the opportunities for risk-sharing among the issuing countries and, thus, the scope for insurance against credit risk is limited because the credit spreads in the Eurozone change commonly, mainly due to exposure of Eurozone countries to the common international risk factors. Moreover, strong member states would have fewer motives for such a model of insurance against credit risk in which they would have to assume the burden of distressed countries. If the Eurobonds implied a transfer of risk away from weaker member states onto strong ones and likely no vice versa too, and if they implied worsening the borrowing conditions for strong member states, the countries with strong fundamentals would not be interested in the Eurobonds. Deteriorating the borrowing conditions for strong member states cannot be excluded. Namely, if the credit quality of the Eurobonds reflected the weighted average of the credit standings of the participating member states, the borrowing costs for strong countries would be higher than yields on their national bonds. However, the credit quality of the Eurobonds would primarily reflect the creditworthiness of larger economies. To the extent that larger economies, as fiscally strong Eurobond issuers, have the excess fiscal capacity to guarantee the Eurobond debt of weaker issuers, credit quality of the Eurobonds would be greater than the weighted average of credit standings of the participating member states. When the quality of Eurobonds reached the quality of national bonds of strong countries, the costs of borrowing in the integrated Eurobond market for strong countries would be the same as yields on their national bonds. If the better credit quality of the common Eurobonds would base on the economic strength and safety of issuers rather than on the risk-sharing opportunities, there would be no economic rationale for the introduction of the common Eurobonds in the euro area. Based on everything previously mentioned, we can conclude that implementing the idea of the common Eurobonds issuance in the Eurozone would not exist without costs for strong member states. It is clear that fiscally strong countries would not gain or they would only little gain from the introduction of common Eurobonds. On the contrary, weaker countries would certainly gain from the introduction of common Eurobonds. The borrowing costs for all weaker countries would decrease by implementing any proposals.

Implementing the idea of the common European government Eurobonds issuance would ensure greater debt management coordination. This greater coordination would arise as a result of the liability of a Eurobond issuing program to accommodate the different needs of participating issuers, such as achieving 
the desired maturity structure, interest structure, redemption plan, safety, etc. On the other hand, flexibility in debt management would be reduced. Country-specific debt management objectives, which would otherwise have to pursuit in the national bond markets, would be more complex to achieve in the integrated Eurobond market. It could make the total debt management in all Eurozone countries the more complex and encourage their opposition to the full market integration. The problem of reduced flexibility in debt management would express differently depending on the type of Eurobond. In the event of implementing the idea of the common Eurobonds issuance by issuing a severally but no jointly guaranteed Eurobonds, country-specific debt management would be the most inflexible. The Eurobonds that are jointly and severally guaranteed by participating member states and those that are issued by an EU institution would allow for "a greater flexibility in accommodating debt management needs because the risk characteristics of each single bond issue would not depend on the amount of funds that each member state would obtain from that issue." 27

Creating the common European Eurobond market could cause either that some existing national markets are closed or that new markets simultaneously operate with the existing national markets. The first option would be very possible if smaller size issuers quickly moved to the Eurobonds in satisfying the funding needs and thus closed their national markets. The implications of such a scenario could be saving the costs of maintaining the national primary markets and dealer systems as well as the appearance of the previously discussed problem of reduced flexibility in the country-specific debt management. Associated with the second scenario, a new market would be added to the existing national markets and, in this way, the market fragmentation would be increased rather than reduced. To achieve market integration and create a thick market, Eurobond issues would have to be regular, permanent, sufficiently large, stable and predictable. Additionally, the level to which the Eurobonds replace the national bonds should be high. Following above mentioned emerges the fact that the success of implementing the idea of the common Eurobonds issuance in the Eurozone hinges on the readiness of participating countries to rely on the new instrument for satisfying their funding needs. The initial costs of transition towards the integrated Eurobond market could be high. Given that the initial costs of the transition process could be high and the expected benefits could be uncertain, participating countries will never be fully ready for the leaving their national markets and move to the integrated Eurobond market.

27 Favero, C.; Missale, A.: EU public debt management and Eurobonds, European Parliament, Policy Department A: Economic and Scientific Policies, 2010, URL: http://www.europarl.europa.eu/document/activities/cont/201106/20110607ATT20897/20110607ATT20897EN.pdf, p. 16. 
In addition to the previously stated implications, a Eurobond solution could have some other effects. Among other things, the common European government Eurobond could become a "safe-haven" alternative to the US Treasuries and improve the position of the euro as an international reserve currency. For this, the instrument should have a credit quality as high as the credit quality of and liquidity greater than the liquidity of German Bunds that are the safest debt instruments in the Eurozone. Furthermore, the common Eurobond market size should reach a similar size of the US Treasuries market. If these conditions were fulfilled, the common instrument could better attract and satisfy the global demand by investors outside the Eurozone for a safe, i.e. risk-free asset and compete with US Treasuries for providing the "safe-haven" than German Bunds. These capabilities of the common European government Eurobond, as well as the fact that German Bunds are in scarce supply, could be sufficient for the common Eurobond to reach the status of a "safe-haven" benchmark. Consequently, the euro would be more used as an international reserve currency. Likewise, the presence of a "lender of last resort" that is ready to buy unlimited amounts of bonds issued by euro area member states, when it is necessary, would enable preventing contagion and the halting of a liquidity crisis. However, it is not certain that both conditions will be fulfilled and thereby it is not certain that the common Eurobond will become a "safe-haven" benchmark.

Implementing the idea of the common Eurobonds issuance in the Eurozone could also have some implications for the moral hazard, incentives for fiscal discipline, market stability and market discipline and crisis prevention. The risk of moral hazard could emerge. The emergence of this risk is possible when some but not each proposal would be implemented. This risk implies the possibility that a euro area member state is tempted to free ride on the legal obligations of other member states to assume its debt in the case of default. Free riders would be fiscally weak countries, i.e. countries with weak fiscal discipline. The problem of moral hazard could be caused by the unlimited access to Eurobonds, the mutualization of risks and the cross-default nature of the joint guarantees on Eurobonds. "Especially if access to Eurobonds is unlimited, countries could lose the incentive to take care of their public finances - they have access to debt financing anyway, based on the guarantee provided by the other EMU countries." 28 "Knowing that at least part of their debt is guaranteed by other countries," fiscally weak countries "will increase their spending and start issuing more debt, because the interest rate on the guaranteed component

28 Gilbert, N. D. et al:: Towards a Stable Monetary Union: What Role for Eurobonds?, De Nederlandsche Bank Working Paper, 379, 2013, URL: https://ssrn.com/abstract=2269538 or http://dx.doi.org/10.2139/ssrn.2269538, p. 18. 
of the debt is (largely) insensitive to an individual debt increase." 29 Provided that the credit risk stemming from a lack of fiscal discipline in individual countries would be shared by all participating countries, the moral hazard may be induced by pooling the default risk. To limit or even eliminate the moral hazard, the maximum amount of each member state debt obligations stemming from the Eurobond issuance should be fixed at a specified percentage of its GDP and additional borrowing needs beyond this threshold should be fulfilled with national bonds. In this way, the obligations of the other member states to guarantee and be liable for repayment of debt of any participating country in the event of its default would be limited. Furthermore, the fact that the Eurobonds could be issued as senior bonds concerning the national bonds and at risk-free interest rate would enforce the member states to discipline their public finances and, thus, to reduce their borrowing costs and to attract investors. Finally, as the legal obligation to assume the debt of another member state in the case of its default could generate the higher costs for countries with sound fiscal policies, "it is politically very hard to "sell" the proposal to taxpayers in these countries. The only solution viable in the long run is a credible commitment by all EMU members to reform and fiscal discipline." ${ }^{30}$ Therefore, fiscal discipline would have to pave the way for an introduction of the common Eurobonds which are no burdened with moral hazard problems, which are cheaper for issuers, which are safer for investors, as well as which are politically more acceptable.

While some authors believe that the introduction of the common Eurobonds will contribute to strengthening the fiscal discipline in the Eurozone, the others disagree. Contrary to the former, the latter considers that the common European bond will undermine the fiscal discipline in the euro area. They argue their viewpoint with the claim that a jointly guaranteed Eurobonds could remove incentives for creating the sound budgetary policies and introducing the budgetary discipline, as these bonds prevent the financial markets from exerting their disciplinary role through higher interest rates and prevent the individual countries to fully confront with the costs of their high debt and deficits. The member states would be encouraged to adopt not so sound fiscal policies and to more borrow because the disciplining effect of higher interest rates is less than expected. Previously stated is also true because the other countries are liable for repayment of debts of individual member states in case of their de-

\footnotetext{
29 Beetsma, R.; Mavromatis, K.: An analysis of Eurobonds, Journal of international money and finance, 45, 2014, p. 92.

30 Eijffinger, S. C.: Eurobonds-Concepts and implications, Briefing Note to the European Parliament, 2011, URL: http://www.sylvestereijffinger.com/wp2/wp-content/uploads/EP\%20 Briefing\%20Paper\%20March\%202011.pdf, p. 10.
} 
fault and, therefore, the member states do not bear the consequences of high debt and default. In other words, the common Eurobond issuance would not solve the fiscal problems of the weakest euro area countries, but would instead prolong and facilitate their reliance on debt. As Gilbert et al. and Favero and Missale stated, this could ultimately lead to the debt level increase for the euro area as a whole and possibly even to raising the interest rates on the Eurobonds themselves, as well as weakening the credibility of the Eurozone as an area of stability and fiscal soundness.

The introduction of the common Eurobonds can be seen as a step towards establishing a fiscal union and therewith towards finalization of the process of creating the economic and monetary union in Europe. Seeing the introduction of the common Eurobonds in this way is tied with a degree of signaled political will for greater fiscal unity and cooperation in the Eurozone, which is shown by the announcement of this idea. However, due to moral hazard risks, there is a fear that the Eurozone could become a so-called transfer union, i.e. union in which well-performing countries pay for weak-performing member states, which would aggravate the crisis and lead to the disintegration of the Eurozone.

The common European Eurobond market would be larger and more stable than the market of any individual country, which would have to enable such a market to protect itself from large swings in market sentiment. Moreover, this market should exert the disciplinary role through differentiating the interest rates which would be charged to governments to be correctly disciplined for good and bad behavior. However, some authors doubt that the common Eurobond market can provide stabilizing and disciplining effects. They believe that the common Eurobond issuance would prevent the financial markets from exerting their stabilizing and disciplinary role. Their doubts associated with the stabilizing and disciplinary role of the common Eurobond issuance stem from the fact that an efficient market mechanism is absent. Possibility of reducing the credit risk premium and therewith the interest rate that weaker euro area countries have to pay on their debts independent of changes in their debt levels and credit standings confirms the absence of efficient market mechanism. In this case, "relying on the disciplinary effects of widening interest rate spreads is weak. Experience shows that market signals, i.e. interest rate spreads, are not only dominated by swings in market sentiment but, more importantly, can remain weak for a long time and change violently when it is too late to prompt fiscal adjustment." ${ }^{\prime 31}$ After the all previously stated, we can state the same as

31 Favero, C.; Missale, A.: EU public debt management and Eurobonds, European Parliament, Policy Department A: Economic and Scientific Policies, 2010, URL: http://www.europarl.europa.eu/document/activities/cont/201106/20110607ATT20897/20110607ATT20897EN.pdf, p. 17. 
Favero and Missale stated: "By preventing financial markets from exerting their disciplinary role, Eurobonds will further reduce the incentives for fiscal adjustment. Interestingly, the argument applies even if the issuance of national bonds continued to remain substantial because lower default risk would translate into lower interest rates on national bond issues (assuming that their seniority would be the same as Eurobonds). In other words, Eurobonds would cross-subsidize the national bonds of weaker Member States." ${ }^{2}$ In the end, it is important to note that the degree of expected market discipline may vary for every proposal.

In the Eurozone, the probability that a crisis propagates from one country to another is particularly high. The reason for crisis propagation is strong real and financial links. The main channel of crisis transmission is through financial links, primarily through cross-border investment in national bonds or through the highly vulnerable European banking system. Another channel of crisis transmission is through trade links. Additionally, a crisis may propagate to other countries because of contagion. A crisis in any euro area country may have a negative influence on the creditworthiness of other countries. If some euro area country defaults on its debt and thereby increases the probability of default in some other countries in the Eurozone too, either due to interdependences in the real and financial sectors or due to contagion, then the halting a crisis in fiscally weaker euro area countries might improve the debt sustainability in fiscally stronger countries. The introduction of common Eurobonds backed by joint guarantees or issued by EU institutions could reduce the risk of crisis propagation in the Eurozone, i.e. the risk of crisis transmission from less fiscally responsible countries to those more responsible, by ensuring both the market access and the borrowing under better conditions for weaker countries during crises. In this way, the reduction of not only default risk exposure of fiscally weaker countries would be ensured, but also the exposure of fiscally stronger countries, as it will not be necessary for the latter countries to take over the debt of the former countries. Given that the introduction of common Eurobonds would enable the countries in fiscal difficulties to retain access to market financing and therewith would prevent the dispersing of a crisis in the Eurozone, it seems that this could bring stability. On the other hand, with the introduction of common Eurobonds, "some member states may increase their debt accumulation since they will have easier access to the financial markets. This would be problematic since the failure of a country to repay may trigger a domino effect if the other countries do not have enough resources to absorb

32 Favero, C.; Missale, A.: Sovereign spreads in the Eurozone: which prospects for a Eurobond?, Economic Policy, 27(70) 2012, p. 231-273. DOI: https://doi.org/10.1111/j.1468 0327.2012.00282.x, p. 254. 
the troubled debt." ${ }^{33}$ Bearing in mind everything previously mentioned, we can conclude that it is not certain whether the introduction of common Eurobonds could bring stability in the euro area or not.

\section{FULFILMENT OF THE LEGAL AND POLITICAL CONDITIONS FOR IMPLEMENTING THE IDEA OF COMMON EUROBONDS ISSUANCE IN THE EUROZONE}

To answer the questions: Is the issuance of the common Eurobonds feasible? Will the common Eurobonds ever be issued? and Is an idea of the common Eurobonds issuance in the Eurozone sustainable?, not only do we need to consider the economic effects of implementing the idea, but also whether the legal and political conditions for the introduction of the common Eurobonds are fulfilled. The discussion on the legal feasibility and political desirability of idea of the common Eurobonds issuance is important because the introduction of common Eurobonds, which would be implemented in accordance with some proposals, would face both legal obstacles and strong political opposition if it was implemented at this moment.

In the discussion on fulfillment of the legal conditions for implementing the idea of common Eurobonds issuance, the central question is whether the Treaty on the Functioning of the European Union (TFEU) leaves room for that. The TFEU does not deal with the issuance of any type of bonds, neither bonds of the EU nor those of member states. Therefore, there are no directly imposed obstacles related to the design of the model according to which the common Eurobonds will be introduced. However, the no-bailout clause, i.e. the letter of Article 125 of the TFEU could make the introduction of the common Eurobonds impossible. "In its current form, Article 125 of the Lisbon Treaty prohibits any member state to be liable for or assume liabilities of other member states." ${ }^{34}$ Whether the no-bailout clause can hinder the introduction of the common Eurobonds in the Eurozone or not depends on the nature of the guarantees underpinning these financial instruments. On the one hand, the issuance of common Eurobonds, in which each participating issuer would be liable only for its share of debt, would not face any legal obstacles. Such issuance could be agreed outside the EU legal framework. On the other hand, the issuance of common Eurobonds underpinned by cross guarantees of the participating

\footnotetext{
33 Tsiropoulos, V.: The effects of Eurobonds, Mimeo Stony Brook University, 2016, URL: http://www.gtcenter.org/Archive/2016/Conf/Tsiropoulos2347.pdf, p. 2.

34 Tielens, J. et al.: Effects of Eurobonds: a stochastic sovereign debt sustainability analysis for Portugal, Ireland and Greece, Journal of Macroeconomics, 42, 2014, p. 156-173. DOI: https://doi.org/10.1016/j.jmacro.2014.06.004,p. 157.
} 
issuers and the issuance of common Eurobonds by some EU institutions may require the changes either in the TFEU or in EU legislation. Thus, for example, the cross-default nature of the joint guarantees of the participating issuers on Eurobonds underpinned by such guarantees violates the no-bailout clause, i.e. the letter of Article 125 of the TFEU. For that reason, the issuance of these types of common Eurobonds may require the changes in the TFEU. In other words, to prepare the ground for Eurobonds jointly guaranteed by the participating issuers from the euro area, the barrier imposed by the letter of Article 125 of the TFEU should be overcome through a Treaty amendment. This is not impossible but implies a long implementation time. However, the dilemma of whether the weakening the no-bailout principle or even excluding the no-bailout clause from the TFEU is wise would cause making a decision on a Treaty amendment difficult. Namely, as the no-bailout clause could be both effective in preventing an irresponsible or even opportunistic behavior of the participating issuers and acceptable for governments of most euro area countries because this clause enables them to halter the crisis before it widens all over the euro area, but also the no-bailout clause could make the introduction of the common Eurobonds impossible, it is difficult to find an appropriate solution. In the case of the common Eurobonds issued by some EU institution the cross guarantees would not be explicit but stem from the EU legal order. Therefore, legal obstacles associated with the possible violation of the no-bailout clause would also exist but they would be different. To overcome them, as well as to enable an EU institution to raise funds for deficit financing, changes in the TFEU would be necessary. Likewise, if some EU institution was allowed to become the issuer of the common Eurobonds, the problem of de facto liability of non-participating euro area countries for the debt of participating issuers, stemming from thr cross guarantee, would have to be solved.

Besides the legal obstacles, the idea of common Eurobonds issuance in the Eurozone faces strong political opposition, especially by politicians from euro area member states with sound fiscal fundamentals and budgetary policies. Reasons hiding behind the political opposition are fears of fiscal discipline relaxation and moral hazard problem emergence and dissatisfaction caused by inequitable sharing of the costs and the benefits from the Eurobond issuance program. Politicians sometimes use the arguments related to legal obstacles to express disagreement with the idea of common Eurobonds issuance in the Eurozone. Whatever the reason for politicians to oppose the idea of common Eurobonds issuance in the Eurozone is, the consequence could be the lack of participation incentives in member states. Simply, no euro area member state will be interested in paying a higher interest rate and guaranteeing or assuming the debt of other countries if it does not receive an appropriate part of all benefits. Given that the lack of political will to implement the idea could be 
a serious obstacle, the issuance of jointly guaranteed Eurobonds requires creating a possibility to overcome a great deal of political resistance. As earlier already shown, some proposals related to the common Eurobonds issuance suggest how the causes of political opposition could be eliminated and thus to encourage the euro area member states to participate in the issuance program. Although solutions to the problems of politicians opposing can be found, certainly, euro area member states will fully accept the idea of the common Eurobonds issuance when an EU common fiscal policy is created and when fiscal integration and political union in the euro area become strong. Only then, the Eurobonds should be of the highest credit quality and acceptable even for the euro area member states with sound fiscal fundamentals.

\section{CONCLUSION}

Since 1993 various proposals for implementing the idea of the issuance of the common Eurobonds in the Eurozone have presented different variants of a model of issuing. The models of issuing the common Eurobonds presented later have offered new solutions from time to time, but they have often been an extension to the models presented earlier. Numerous proposals offer a possibility for the issuance of common Eurobonds to be seen from different perspectives, but they also make the idea highly controversial.

The expected economic effects of implementing the idea of the common Eurobonds issuance in the Eurozone are different. There is no dilemma on implications of implementing the idea of issuance of the common Eurobonds for the liquidity of European bond markets, for the access to the financial markets and insurance against credit risk for all member states, for the debt management coordination, the thick market set-up costs, the positions both of the common European government Eurobond as a "safe-haven" alternative to the US Treasuries and of the euro as an international reserve currency. These implications are positive. However, the implications for flexibility in debt management are negative. Flexibility in debt management would reduce. The negative implications for the moral hazard could exist, i.e. the risk of moral hazard could emerge if some but not each proposal was implemented. The implications for the borrowing costs would not be the same for all member states. Namely, borrowing costs for all fiscally weaker countries would decrease. For fiscally strong countries, the costs of borrowing in the integrated Eurobond market would be the same as yields on their national bonds when the quality of Eurobonds reached the quality of national bonds of strong countries. However, if the credit quality of the Eurobonds reflected the weighted average of the credit standings of the participating member states, the borrowing costs for fiscally strong countries would be higher than yields on their national bonds. Finally, 
it is not certain whether the introduction of common Eurobonds could contribute to strengthening the fiscal discipline, prevent the financial markets from exerting their stabilizing and disciplinary role and bring stability in the euro area. Fears of fiscal discipline relaxation and moral hazard problem emergence and dissatisfaction caused by inequitable sharing of the costs and the benefits from the Eurobond issuance program cause the strong political opposition, particularly by politicians from euro area member states with sound fiscal fundamentals and budgetary policies, to the idea of common Eurobonds issuance in the Eurozone. Not only do the expected negative economic effects of implementing the idea of the common Eurobonds issuance in the Eurozone cause the strong political opposition to the idea, but also the legal obstacles which require the changes either in the TFEU or in EU legislation.

Provided that a large number of proposals presented so far make the idea a highly controversial and the possible bi-directionality in manifesting the economic effects and the political opposition additionally makes the controversy stronger, it is clear that the implementation of the idea of the common Eurobonds issuance in the Eurozone is not possible under these conditions. However, the idea could be sustainable in the future if fiscal integration and political union in the euro area became strong. To check the sustainability of the idea in the future, it is necessary to investigate the possible costs and benefits of the introduction of the common Eurobonds if the fiscal and political union were created. Therefore, future research could be aimed at investigation of the influence of fiscal and political union creation on the sustainability of the idea of the common Eurobonds issuance in the Eurozone. The future research could also be directed at considering the possibility of gradually introducing the common Eurobonds by issuing them inside the participating Eurobond issuers union. This union could consist of euro area member states which achieve the consensus on conditions under which the highest quality common Eurobonds can be issued and which satisfy these conditions. The union would gradually widen as new countries satisfy the participation conditions. In other words, future research could be aimed at considering the possibility to develop the common Eurobond market after the creation of fiscal and political union and the possibility to gradually develop the common Eurobond market, which will lead to the creation of fiscal and political union in the Eurozone.

\section{LITERATURE}

1. Baglioni, A.; Cherubini, U.: Eurobonds: A Quantitative Approach, Review of Law \& Economics, 12(3) 2016, p. 507-521.

-DOI: https://doi.org/10.1515/rle-2016-0041 
2. Beetsma, R.; Mavromatis, K.: An analysis of Eurobonds, Journal of international money and finance, 45, 2014, p. 91-111.

-DOI: https://doi.org/10.1016/j.jimonfin.2014.03.002

3. Claessens, S. et al.: Paths to Eurobonds, International Monetary Fund,WP/12/172, 2012, URL: https://www.imf.org/en/Publications/WP/Issues/2016/12/31/ Paths-to-Eurobonds-26034

-DOI: https://doi.org/10.5089/9781475505207.001

4. Delpla, J.; Von Weizsäcker, J.: Eurobonds: The blue bond concept and its implications, Bruegel policy contribution, 2011/02, 2011, Bruegel, Brussels, URL: http://hdl.handle.net/10419/45535

5. Eijffinger, S. C.: Eurobonds-Concepts and implications, Briefing Note to the European Parliament, 2011, URL: http://www.sylvestereijffinger.com/wp2/wp-content/uploads/EP\%20Briefing\%20Paper\%20March\%202011.pdf

6. Favero, C.; Missale, A.: EU public debt management and Eurobonds, European Parliament, Policy Department A: Economic and Scientific Policies, 2010, URL: http://www.europarl.europa.eu/document/activities/cont/201106/20110607ATT20897/20110607ATT20897EN.pdf

7. Favero, C.; Missale, A.: Sovereign spreads in the Eurozone: which prospects for a Eurobond?, Economic Policy, 27(70) 2012, p. 231-273.

-DOI: https://doi.org/10.1111/j.1468-0327.2012.00282.x

8. Favero, C. A.; Missale, A.: Contagion in the EMU-the role of Eurobonds with OMTs, Review of Law \& Economics, 12(3) 2016, p. 555-584.

-DOI: https://doi.org/10.1515/rle-2016-0043

9. Gilbert, N. D. et al.: Towards a Stable Monetary Union: What Role for Eurobonds?, De Nederlandsche Bank Working Paper, 379, 2013, URL: https://ssrn. com/abstract $=2269538$

-DOI: http://dx.doi.org/10.2139/ssrn.2269538

10. Gopal, M.; Pasche, M.: Market-based Eurobonds Without Cross-Subsidisation, Working Papers on Global Financial Markets from Friedrich-Schiller-University Jena and University of Hall. Wittenberg, Foundations of Global Financial Markets - Stability and Change, 2012-37, 2012, URL: http://hdl.handle.net/10419/94482

11. Hild, A. M. et al.: Structured eurobonds: Limiting liability and distributing profits, JCMS: Journal of Common Market Studies, 52(2) 2014, p. 250-267.

-DOI: https://doi.org/10.1111/jcms.12104

12. Migiakis, P. M.: Reviewing the proposals for common bond issuances by the euro-area sovereign under a long-term perspective, Economic Bulletin, 37, 2012, Bank of Greece, p. 43-54. URL: https://www.bankofgreece.gr/BogEkdoseis/econbull201212.pdf

13. Muellbauer, J.: Conditional eurobonds and the Eurozone sovereign debt crisis, Oxford Review of Economic Policy, 29(3) 2013, p. 610-645.

-DOI: https://doi.org/10.1093/oxrep/grt032 
14. Quadrio Curzio, A.: On the Different Types of Eurobonds, Economia politica, 28(3) 2011, p. 279-294.

-DOI: 10.1428/35912 URL: https://www.rivisteweb.it/doi/10.1428/35912

15. Tielens, J. et al.: Effects of Eurobonds: a stochastic sovereign debt sustainability analysis for Portugal, Ireland and Greece, Journal of Macroeconomics, 42, 2014, p. 156-173.

-DOI: https://doi.org/10.1016/j.jmacro.2014.06.004

16. Tsiropoulos, V.: The effects of Eurobonds, Mimeo Stony Brook University, 2016, URL: http://www.gtcenter.org/Archive/2016/Conf/Tsiropoulos2347.pdf

17. Waibel, M.: Eurobonds: Legal Design Features, Review of Law \& Economics, 12(3) 2016, p. 635-657.

-DOI: https://doi.org/10.1515/rle-2016-0046 